\title{
Neuro protective effect of barbiturates leading to successful cerebral recovery after drug induced cardiac arrest and following severe multi organ fail
}

Mikka Borup ${ }^{1 *}$, Line Overholt Nielsen ${ }^{2 \dagger}$

From 4th Danish Emergency Medicine Conference

Roskilde, Denmark. 25-26 November 2011

\section{Background}

Barbiturates are known to have a neuro protective effect if given prior to cerebral ischemia. Often in cardiac arrest cases the cerebral ischemia occurs before barbiturates can be administrated.

\section{Methods}

Case report.

\section{Results}

23 year old woman suffered cardiac arrest due to a combined drug overdose with high doses of barbiturates, benzodiazepines and opioids. The patient was found unconscious and after 8 minutes of successful resuscitation transferred to the ICU where she rapidly developed multi organ failure due to the hypoxia and hypo perfusion during the time of cardiac arrest. The organ failure included lever, kidney, lung, pancreas and coagulation, but due to the neuron protective effect of barbiturates, there were no symptoms of cerebral damage. After weeks of stabilizing organ functions the patient was discharged with sustained damage to the kidneys, but no sign of cerebral damage.

\section{Conclusion}

In this case the patients self administration of the barbiturates prior to the cardiac arrest proved to be perfect timed and resulted in an optimal cerebral protection. Brian P. Head et. al (2007) has shown that barbiturates

\footnotetext{
* Correspondence: mibo@rn.dk

† Contributed equally

1 Department of anaesthetics, Sygehus Vendsyssel, Hjørring, Denmark
}

Full list of author information is available at the end of the article

administrated after a hypoxic period still can have a protective effect. Therefore barbiturates can play a crucial role in preventing cerebral damage given both prior to and after ischemic insult.

\section{Author details}

'Department of anaesthetics, Sygehus Vendsyssel, Hjørring, Denmark.

${ }^{2}$ Department of cardiology, Aalborg Sygehus, Denmark.

Published: 16 April 2012

doi:10.1186/1757-7241-19-S2-P32

Cite this article as: Borup and Nielsen: Neuro protective effect of barbiturates leading to successful cerebral recovery after drug induced cardiac arrest and following severe multi organ fail. Scandinavian Journal of Trauma, Resuscitation and Emergency Medicine 2012 19(Suppl 2):P32.

Submit your next manuscript to BioMed Central and take full advantage of:

- Convenient online submission

- Thorough peer review

- No space constraints or color figure charges

- Immediate publication on acceptance

- Inclusion in PubMed, CAS, Scopus and Google Scholar

- Research which is freely available for redistribution

Submit your manuscript at www.biomedcentral.com/submit ( Biomed Central 